\title{
Effect of COVID-19 pandemic-induced lockdown (general holiday) on air quality of Dhaka City
}

\author{
Md. Saiful Islam (D) Tahmid Anam Chowdhury
}

Received: 14 July 2020 / Accepted: 2 May 2021 / Published online: 17 May 2021

(C) The Author(s), under exclusive licence to Springer Nature Switzerland AG 2021

\begin{abstract}
A worldwide pandemic of COVID-19 has forced the Government of Bangladesh to implement a lockdown during April-May 2020 by restricting people's movement; shutdown of industries and motor vehicles; and closing markets, public places, and schools to contain the virus. This type of strict measures caused an outcome, the reduction of urban air
\end{abstract}

Supplementary Information The online version contains supplementary material available at https://doi. org/10.1007/s10661-021-09120-z.

\section{Highlights}

1. The concentration of fine particulate matter (PM ) has decreased by $26 \%$ during the lockdown period.

2. The concentrations of $\mathrm{NO}_{2}, \mathrm{SO}_{2}$, and $\mathrm{CO}$ have decreased by 30,07 , and $07 \%$, respectively.

3. The Air Quality Index has decreased by about $35 \%$ on average.

M. Islam ( $\bowtie)$

EQMS Consulting Limited, House 53, Road 4, Block C, Banani, Dhaka 1213, Bangladesh

e-mail: mdsaiful91@gmail.com; saiful.islam@eqms.com. bd

T. A. Chowdhury

Remote Sensing Division, Center for Environmental and Geographic Information Services, House 6, Road 23/C, Gulshan-1, Dhaka 1212, Bangladesh

Present Address:

T. A. Chowdhury

Anam House, College Road, Biraimpur,

Sreemangal, Moulvibazar 3210, Bangladesh pollution, around the world. The present study aims to investigate the reduction of the concentration of pollutants in the air of Dhaka City and the reduction of the Air Quality Index (AQI). Necessary time-series data of the concentration of $\mathrm{PM}_{2.5}, \mathrm{NO}_{2}, \mathrm{SO}_{2}$, and $\mathrm{CO}$ have been collected from the archive of the Air Quality Monitoring Station of the US Embassy in Dhaka and Sentinel-5P. The time-series data have been analyzed by descriptive statistics, and AQI was calculated following an appropriate formula suggested by the Environmental Protection Agency (EPA) based on the criteria pollutants. The study found that the concentrations of $\mathrm{PM}_{2.5}, \mathrm{NO}_{2}, \mathrm{SO}_{2}$, and $\mathrm{CO}$ during April-May 2020 have been reduced by 26, 30, 07, and $07 \%$, respectively, compared with the preceding year's concentrations. Moreover, the AQI has also been reduced by about $35 \%$ on average during the lockdown period than the same times of the previous year. However, the magnitude of pollution reduction in Dhaka is lower than in other cities and countries globally, including Delhi, Sao Paulo, Wuhan, Spain, Italy, the USA. The main reasons may include, among others, the poor implementation of lockdown (especially in the first week of April and the second fortnight of May), pre-existing pollution, transboundary pollution, incineration of solid waste, etc. This study will help policymakers figure out how to regulate pollution sources and improve the air quality of Dhaka.

Keywords Air quality · COVID-19 pandemic . Lockdown · Air Quality Index · Dhaka megacity 


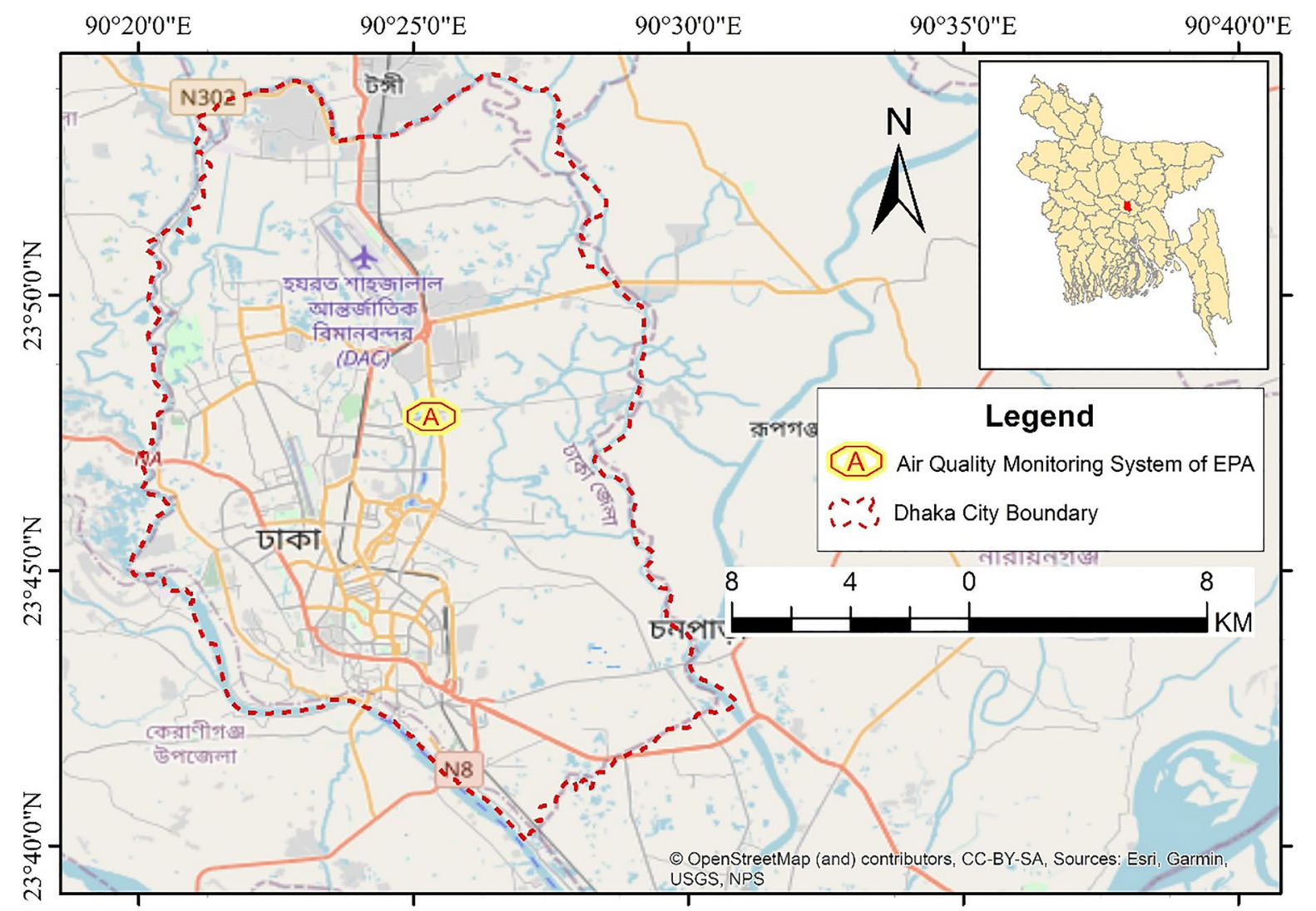

Fig. 1 Map of Dhaka showing the location of air quality monitoring station

\section{Introduction}

Nowadays, the ambient air quality of an urban area has become a significant concern for city dwellers worldwide because of its substantial impact on health, ecology, and climate change (IPCC, 2007; Van Tienhoven \& Scholes, 2003; WHO, 2006). From a medical perspective, air pollution is not only responsible for respiratory diseases like bronchitis and asthma but also responsible for cancer and cardiovascular disease (Brook et al., 2004). Several studies found a correlation between inhalable particulate matter and mortality and morbidity (Lin \& Lee, 2004; Namdeo \& Bell, 2005; Perez \& Reyes, 2002). An urban area with high population density and weak organizational capacity for controlling the source of pollution is at high risk of air pollution, including both fine $\left(\mathrm{PM}_{2.5}\right)$ and coarse $\left(\mathrm{PM}_{10}\right)$ particulate matter. In this sense, the megacity Dhaka is one of the hotspots of air pollution for its distinct natures like high population density, unfit vehicle movement that emits fine particles due to the combustion of fossil fuel, weak legislative and organizational capacity, dust, and industrial emission in and around the city. According to an estimation, the total population of Dhaka stands more than 15 million, with a density of 33,878 per square kilometer, which is the highest figure in the world (Demographia, 2020). Figure 1 shows a map of the study area-Dhaka City.

In recent years, Dhaka has been repeatedly reported as one of the most polluted cities in the world in terms of $\mathrm{PM}_{2.5}$ concentration and Air Quality Index (AQI) (IQAir, 2018, 2019, 2020). Most of the time, this city is always listed among the top five and or top ten cities with poor air quality. The Department of Environment (DOE) of the Government of Bangladesh reported that the emission from motor vehicles and brick kilns in and around the city are primary sources of particulate matter in the air of Dhaka City (DOE, 2019). An assessment by Begum et al. 
(2013) using receptor modeling suggests that about $22 \%$ and $36 \%$ of fine particulate matter in the air of Dhaka were originated from the brick kiln and vehicle emission, respectively. Moreover, roadside dirt is one of the major sources of dust or coarse particulate matter, especially during the dry season from November to February. Furthermore, concurrent construction work of different mega projects is another main source of air pollution in the city.

However, the global pandemic of COVID-19, originating from China in December 2019, has forced people to restrict their movement and shut down the operation of industries around the world. The Government of Bangladesh also declared a general holiday, which is mainly a lockdown, in the last week of March 2020 to contain the virus. Suddenly, the movement of motor vehicles was barred except for emergency transport like medicine, food, etc. The industries in and around Dhaka city, including the brick kilns, were remained closed. In these circumstances, a worldwide reduction of pollution was observed, especially in urban areas. An estimation found that public mobility was reduced by $90 \%$ due to the pandemic that results in a reduction of pollution by almost $30 \%$ in the epicenters of the disease like Wuhan, Italy, Spain, and the USA (Muhammad et al., 2020). Similar air pollution reduction results have also been found in the neighboring country's capital city, viz. Delhi (e.g., Mahato et al., 2020; Sharma et al., 2020). Moreover, Nakada and Urban (2020) found that the concentrations of $\mathrm{NO}, \mathrm{NO}_{2}$, and $\mathrm{CO}$ have significantly been reduced in São Paulo, Brazil, during a partial lockdown for the COVID-19 pandemic.

Since Dhaka is one of the top polluted cities in the world, it is necessary to investigate and understand the effect of this lockdown on the air pollution of this city. It is anticipated that there would be a significant impact of lockdown on air quality that might improve the city air. In these circumstances, this study intends to investigate the reduction of air pollution in Dhaka-one of the world's biggest megacities. To investigate the air quality before and during lockdown period, the concentration of fine particulate matter $\left(\mathrm{PM}_{2.5}\right)$ and the concentration of various gaseous substances $\left(\mathrm{NO}_{2}, \mathrm{SO}_{2}, \mathrm{CO}\right)$ have been analyzed. Then, the Air Quality Index was computed against the concentration of different pollutants as well as the difference between the occurrence of various AQI classes before and during lockdown was examined.
Furthermore, a comparison of the concentrations of $\mathrm{NO}_{2}, \mathrm{SO}_{2}$, and $\mathrm{CO}$ during April 2019 and 2020 was assessed from satellite images applying remote sensing techniques to illustrate a graphical presentation. In short, the objectives of this study are as follows:

I. To investigate the reduction in the concentration of $\mathrm{PM}_{2.5}, \mathrm{NO}_{2}, \mathrm{SO}_{2}$, and $\mathrm{CO}$ in the air of Dhaka City during COVID-19-induced lockdown compared to the same period of previous years.

II. To examine the changes in the occurrence of different Air Quality Index classes in Dhaka City during the lockdown period.

\section{Materials and methods}

\section{Data source}

This research is based on secondary time-series data of the concentration of $\mathrm{PM}_{2.5}$ during April-May from 2016 to 2020 and the concentrations of $\mathrm{NO}_{2}, \mathrm{SO}_{2}$, CO from 2019 to 2020, and their corresponding AQI values. The time-series data of $\mathrm{PM}_{2.5}$ were collected from the archive of a real-time air quality monitoring system maintained by the United States Environmental Protection Agency (US EPA), which is located in the US Consulate of Dhaka. The Air Quality Monitoring Station is installed on a rooftop in an urban setting. The surroundings of the monitoring station are built-up areas, including residential and commercial land use with sufficient road connectivity and regular traffic movement. Although the target year of this study is 2020 and 2019, the data of $\mathrm{PM}_{2.5}$ in previous 3 years have also been collected to show the change in the level of pollution. The concentration of $\mathrm{PM}_{2.5}$ is measured on an hourly basis. Apart from the raw concentration of the pollutant on an hourly basis, US EPA also calculates NowCast data based on the weighted average of most recent 12 -h data to determine AQI. In this study, the NowCast concentration of $\mathrm{PM}_{2.5}$ has been considered instead of the hourly raw concentration to estimate AQI values. On the other hand, the daily and annual average was calculated from hourly raw data. Besides, the time-series data of the concentration of $\mathrm{NO}_{2}, \mathrm{SO}_{2}$, and $\mathrm{CO}$ during April-May in 2019 and 2020 have been assessed from the Sentinel-5P satellite applying remote sensing techniques. 
Table 1 Classes of AQI values and their health implications

\begin{tabular}{|c|c|c|}
\hline AQI level & Numeric value & Meaning \\
\hline Good & $0-50$ & Air quality is considered satisfactory, and air pollution poses little or no risk \\
\hline Moderate & $51-100$ & $\begin{array}{l}\text { Air quality is acceptable; however, for some contaminants, there may be a moderate health concern } \\
\text { for a very small number of people who are unusually sensitive to air pollution }\end{array}$ \\
\hline $\begin{array}{l}\text { Unhealthy for } \\
\text { sensitive } \\
\text { groups }\end{array}$ & $101-150$ & $\begin{array}{l}\text { Members of vulnerable groups can experience effects on health. The public at large is unlikely to } \\
\text { be affected }\end{array}$ \\
\hline Unhealthy & $151-200$ & $\begin{array}{l}\text { Everyone can start experiencing health effects; members of sensitive groups may experience more } \\
\text { serious effects on health }\end{array}$ \\
\hline Very unhealthy & $201-300$ & Health warnings of state of emergency. It is more likely that the entire population will get affected \\
\hline Hazardous & $301-500$ & Health alert: more severe health effects will affect everyone \\
\hline
\end{tabular}

US EPA (2018)

Some quality check measures have been performed before analysis of the hourly concentration of $\mathrm{PM}_{2.5}$. There were some missing and invalid values already identified by the producers in the data series. That means the time-series data of $\mathrm{PM}_{2.5}$ undergone a quality check before making them available for general use. The missing values were interpolated using the linear interpolation method and the invalid values were omitted during the present analysis.
Air quality index

The Air Quality Index is generally calculated by various government organizations to report how contaminated the current air is or how polluted it will be. The AQI has been calculated from the NowCast concentration of $\mathrm{PM}_{2.5}$ (from 2016 to 2018) and the concentration of different pollutants, e.g., $\mathrm{PM}_{2.5}, \mathrm{NO}_{2}, \mathrm{SO}_{2}$, CO (from 2019 to 2020), using the following formula
Table 2 Descriptive statistics of $\mathrm{PM}_{2.5}$ concentration during AprilMay (lockdown period)

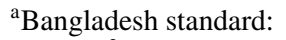
$65 \mu \mathrm{g} / \mathrm{m}^{3}$ (24-h averaging period).

${ }^{\mathrm{b}}$ WHO standard: $25 \mu \mathrm{g} / \mathrm{m}^{3}$ (24-h averaging period).

\begin{tabular}{|c|c|c|c|c|c|}
\hline \multirow[t]{2}{*}{ Criteria } & \multicolumn{5}{|c|}{ Descriptive statistics of $\mathrm{PM}_{2.5}$ during April-May } \\
\hline & 2020 & 2019 & 2018 & 2017 & 2016 \\
\hline \multicolumn{6}{|l|}{ NowCast concentration } \\
\hline Mean $\left(\mu \mathrm{g} / \mathrm{m}^{3}\right)$ & 50.0 & 64.8 & 55.9 & 55.2 & 50.6 \\
\hline $\operatorname{Maximum}\left(\mu \mathrm{g} / \mathrm{m}^{3}\right)$ & 220 & 431 & 373 & 268 & 159 \\
\hline Minimum $\left(\mu \mathrm{g} / \mathrm{m}^{3}\right)$ & 6 & 8 & 5 & 12 & 8 \\
\hline Mode $\left(\mu \mathrm{g} / \mathrm{m}^{3}\right)$ & 61 & 43 & 42 & 46 & 47 \\
\hline Standard deviation $\left(\mu \mathrm{g} / \mathrm{m}^{3}\right)$ & 29.7 & 43.9 & 36.0 & 29.5 & 20.3 \\
\hline \multicolumn{6}{|l|}{ Daily mean (24-h averaging period) } \\
\hline Average of daily mean $\left(\mu \mathrm{g} / \mathrm{m}^{3}\right)$ & 49.7 & 67.2 & 56.3 & 55.3 & 50.6 \\
\hline Maximum of daily mean $\left(\mu \mathrm{g} / \mathrm{m}^{3}\right)$ & 124 & 230 & 186.9 & 149.9 & 89 \\
\hline Minimum of daily mean $\left(\mu \mathrm{g} / \mathrm{m}^{3}\right)$ & 18 & 33 & 23.6 & 20.6 & 16 \\
\hline $\operatorname{Mode}\left(\mu \mathrm{g} / \mathrm{m}^{3}\right)$ & 29 & 56 & 50 & 40 & 55 \\
\hline Standard deviation $\left(\mu \mathrm{g} / \mathrm{m}^{3}\right)$ & 21.2 & 33.4 & 27.3 & 21.4 & 13.8 \\
\hline Daily mean exceeded national standard $(\%)^{\mathrm{a}}$ & 16.7 & 37.3 & 29.8 & 19.7 & 9.8 \\
\hline Daily mean exceeded WHO standard (\%) & 94.4 & 100 & 96.5 & 98.4 & 96.7 \\
\hline No. of days exceeded national standard ${ }^{\mathrm{a}}$ & 10 & 23 & 18 & 12 & 6 \\
\hline No. of days exceeded WHO standard ${ }^{\mathrm{b}}$ & 58 & 61 & 59 & 60 & 59 \\
\hline \multicolumn{6}{|l|}{ Annual mean } \\
\hline Yearly average $\left(\mu \mathrm{g} / \mathrm{m}^{3}\right)$ & 74.9 & 87.0 & 99.4 & 79.86 & 67.8 \\
\hline National standard for annual mean $\left(\mu \mathrm{g} / \mathrm{m}^{3}\right)$ & 15 & & & & \\
\hline WHO standard for annual mean $\left(\mu \mathrm{g} / \mathrm{m}^{3}\right)$ & 10 & & & & \\
\hline
\end{tabular}


(Eq. 1) (US EPA, 2018). This formula returns a number on a scale of $0-500$.

$I_{\mathrm{P}}=\frac{I_{\mathrm{Hi}}-I_{\mathrm{Lo}}}{\mathrm{BP}_{\mathrm{HI}}-\mathrm{BP}_{\mathrm{Lo}}}\left(C_{\mathrm{P}}-\mathrm{BP}_{\mathrm{Lo}}\right)+I_{\mathrm{Lo}}$

Here,

$I_{\mathrm{P}}=$ the index for pollutant $\mathrm{p}$.

$C_{\mathrm{P}}=$ the truncated concentration of pollutant $\mathrm{p}$.

$\mathrm{BP}_{\mathrm{Hi}}=$ the concentration breakpoint that is greater than or equal to $C_{\mathrm{P}}$.

$\mathrm{BP}_{\mathrm{Lo}}=$ the concentration breakpoint that is less than or equal to $C_{\mathrm{P}}$.

$I_{\mathrm{Hi}}=$ the $\mathrm{AQI}$ value corresponding to $\mathrm{BP}_{\mathrm{Hi}}$.

$I_{\mathrm{Lo}}=$ the $\mathrm{AQI}$ value corresponding to $\mathrm{BP}_{\mathrm{Lo}}$.

The breakpoints and their corresponding AQI values of $\mathrm{PM}_{2.5}, \mathrm{SO}_{2}, \mathrm{NO}_{2}$, and $\mathrm{CO}$ can be found in Appendix (Table 6). The values of AQI are divided into six classes: (i) Good, (ii) moderate, (iii) unhealthy for sensitive groups, (iv) unhealthy, (v) very unhealthy, and (vi) hazardous. Table 1 shows the potential health implications against each of these classes of AQI. In this study, we have calculated AQI based on $\mathrm{PM}_{2.5}$ from 2016 to 2018 as the time-series data of the concentration of other criteria pollutants are not available for this period. However, when the concentration data of other criteria pollutants are available, AQI is normally calculated for each pollutant separately, and the highest value is reported (US EPA, 2018). Since the time-series data of $\mathrm{NO}_{2}, \mathrm{SO}_{2}$, and CO is available from April-May 2019 to 2020, AQI was calculated for all pollutants in this period and the highest value was considered for analysis.

\section{Assessment of gaseous substances}

Real-time atmospheric monitoring data of $\mathrm{NO}_{2}, \mathrm{SO}_{2}$, and CO during April-May in 2019 and 2020 have been collected from the Sentinel-5P satellite. The Sentinel-5 Precursor mission instrument collects data that are useful for assessing air quality. The TROPOMI instrument of Sentinel-5P is a multispectral sensor that records the reflectance of wavelengths, which are essential for measuring atmospheric concentrations of different gases and cloud characteristics at a spatial resolution of 0.01 arc degrees. The Sentinel-5P sensor measures the concentration of gaseous pollutants along with the depth of the entire vertical column over the study area in the $\mathrm{mol} / \mathrm{m}^{2}$ unit. In addition to time-series data, the concentration of gaseous substances has been extracted during the last week of April in 2019 and 2020 and presented in a raster format to compare the "before lockdown" and "during lockdown" scenario.

\section{Results}

Changes in concentration of $\mathrm{PM}_{2.5}$

The concentration of $\mathrm{PM}_{2.5}$ in April and May has been analyzed by descriptive statistics technique based on both NowCast concentration and 24-h averaging period (daily mean). Table 2 presents the findings of the statistical analysis of the data between 2016 and 2020. The findings show that the mean concentration of $\mathrm{PM}_{2.5}$ based on a 24-h averaging period in 2020 has been decreased by about $26 \%$ than the mean concentration of 2019. On the other hand, the decreasing rate is about $12 \%$ and $10 \%$ compared to the mean concentration of 2018 and 2017. The maximum concentration of fine particulate matter in 2020 is also decreased by about $46 \%$ of its concentration in 2019. Almost $17 \%$ of observations exceeded the national standard limit (65 $\mu \mathrm{g} / \mathrm{m}^{3}$ for the $24-\mathrm{h}$ averaging period) in 2020 , whereas it was slightly higher than $37 \%$ in 2019 . The reduction, in this case, is about 55\% comparing the percentage of over standard daily mean values in 2020 to its counterpart in 2019. In addition to the national standard, a comparison with the standard set by the World Health Organization (WHO) has also been shown in Table 2. The value of standard deviation also shows that the data series of 2020 is less discrete than the data series of 2019. It implies that the data of 2020 have not varied widely; instead, it shows more closeness and compactness than 2019. In other words, the 2020 data during the lockdown period of April-May observed fewer extreme values than the same period of previous years. Table 2 also shows that the annual mean of $\mathrm{PM}_{2.5}$ in 2020 decreased by more than $16 \%$ than the annual mean value of 2019. Interestingly, the decreasing rate of the annual mean is less than the decreasing rate during the lockdown period. The probable reason may include the accelerating emissions after withdrawal of lockdown that affected the overall yearly average. 
Fig. 2 Time-series plots of $\mathrm{NO}_{2}, \mathrm{SO}_{2}$, and $\mathrm{CO}$ during April-May 2019 and 2020

$\mathrm{NO}_{2}$ in April-May 2019-2020

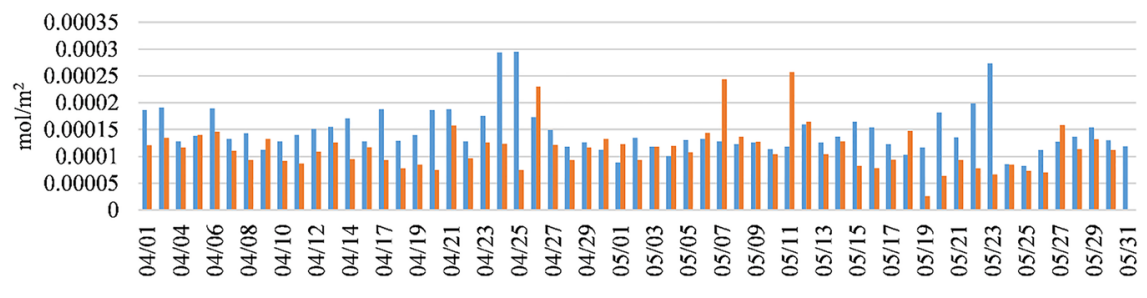

NO2 in April-May $2019 \square$ NO2 in April-May 2020

$\mathrm{SO}_{2}$ in April-May 2019-2020
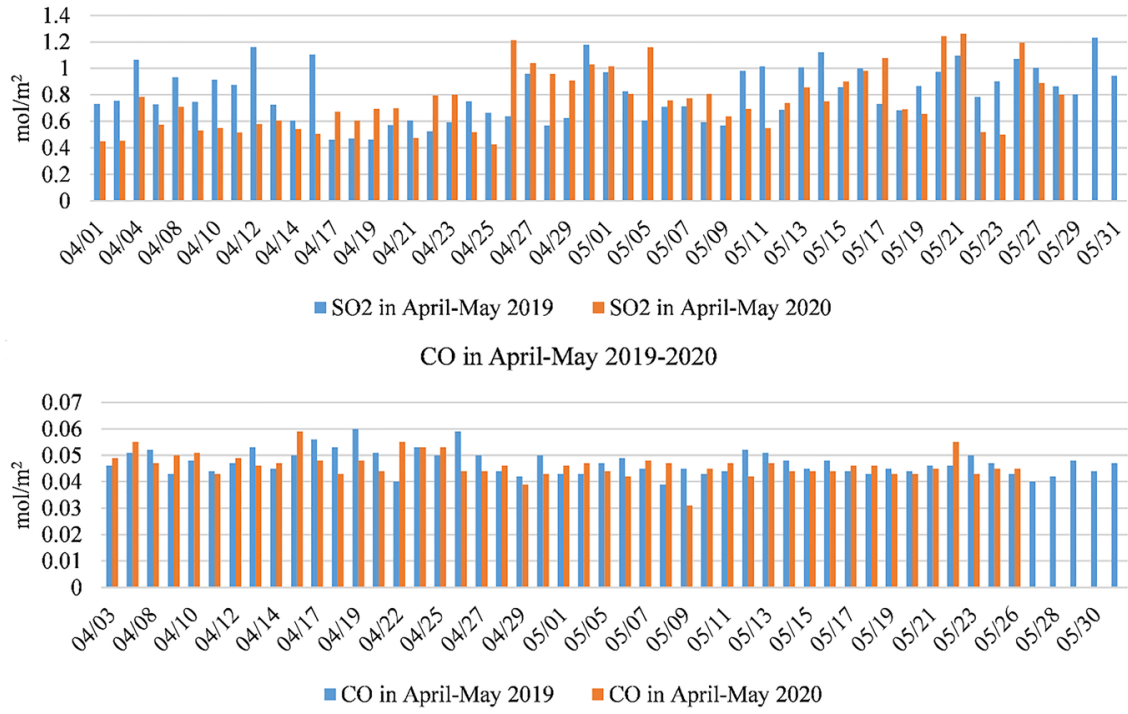

Changes in gaseous substances

Another noteworthy finding is that the mean concentrations of 2016 and 2020 during April-May are almost the same. Table 2 implies that after 2016, the concentration of fine particulate matter $\left(\mathrm{PM}_{2.5}\right)$ has increased significantly throughout 2017-2019. In 2019, the air quality of Dhaka had experienced the worst scenario in recent history. During the lockdown period of April-May in 2020, the air quality has definitely improved, but it did not cross the concentration of 2016. The time-series graphs of the daily average concentration of $\mathrm{PM}_{2.5}$ during April-May in 2020, 2019, 2018, 2017, and 2016 can be found in Online Resource 1 (Supplementary Information). The graph of 2020 indicates that $\mathrm{PM}_{2.5}$ concentration in the first week of April was relatively higher. It is because it took some time to implement the lockdown strictly in the first week of April. On the other hand, some industries like Ready Made Garments have resumed their work in the second fortnight of May that triggered a limited movement of public vehicles in and around the city.
The criteria pollutants of air include some gaseous substances, such as $\mathrm{NO}_{2}, \mathrm{SO}_{2}$, and $\mathrm{CO}$, which are mainly released from motor vehicles (due to fossil fuel combustion), wood combustion, biomass burning, from small businesses using combustion techniques and industrial activities (e.g., brick kilns), etc. Since daily time-series data from ground-based realtime monitoring systems for these gaseous substances are not available, necessary information has been extracted from satellite imageries. Figure 2 shows the time-series plot of the concentration of gaseous substances in April-May 2019 and 2020. The findings of time-series data analysis, presented in Table 3, show that the mean and the maximum concentration of $\mathrm{NO}_{2}$ in April-May 2020 have been reduced by about 30 and $22 \%$, respectively, compared to the same period of 2019. In the case of CO, the mean and maximum concentration has been reduced by about $7 \%$ 
Table 3 The concentration of gaseous substances during April-May 2020 and 2019

\begin{tabular}{|c|c|c|c|c|}
\hline \multirow[t]{2}{*}{ Pollutant } & \multicolumn{2}{|c|}{ April-May 2020} & \multicolumn{2}{|c|}{ April-May 2019} \\
\hline & Mean & Maximum & Mean & Maximum \\
\hline Nitrogen dioxide $/ \mathrm{NO}_{2}\left(\mathrm{~mol} / \mathrm{m}^{2}\right)$ & 0.000102 & 0.000230 & 0.000146 & 0.000295 \\
\hline Sulfur dioxide $/ \mathrm{SO}_{2}\left(\mathrm{~mol} / \mathrm{m}^{2}\right)$ & 0.757 & 1.120 & 0.811 & 1.231 \\
\hline Carbon monoxide/CO $\left(\mathrm{mol} / \mathrm{m}^{2}\right)$ & 0.043 & 0.057 & 0.047 & 0.060 \\
\hline
\end{tabular}

and 5\%, respectively, compared to the previous year. Similarly, the mean concentration of $\mathrm{SO}_{2}$ has been decreased in April-May 2020 by about 7\% compared with the mean concentration in April-May 2019. Since $\mathrm{NO}_{2}$ has a closer link to motor traffic emissions, the reduction of this pollutant is more dominant (in comparison to $\mathrm{PM}_{2.5}$ and other pollutants) in the lockdown period. Figure 3 shows a graphical presentation of the changes in the concentration of $\mathrm{NO}_{2}, \mathrm{SO}_{2}$, and CO over Dhaka during the last week of April 2019 and 2020.

Changes in air quality index

The Air Quality Index has been computed against the NowCast concentration of $\mathrm{PM}_{2.5}$ from 2016 to 2018 using the formula in Eq. 1. For the 2019-2020 period, the AQI is calculated for all pollutants separately, and the highest value is considered for analysis. Figure 4 shows the percentage of the occurrence of each class of AQI in different years in tabular format as well as their graphical illustration. According to the findings, the percentage of the occurrence of "unhealthy" and "very unhealthy" levels of AQI has been increased over the years from 2016 to 2019. In contrast, both levels of AQI have been decreased in 2020 by about $21 \%$ and $59 \%$, respectively, compared to the pollution level in 2019. Similarly, the percentage of "unhealthy for sensitive groups" in 2020 has also been decreased by about one-fourth of its occurrence in 2019. On the other hand, the occurrence of "good" and "moderate" AQI levels has been increased in 2020 by about 9 and 2 times, respectively, than their occurrences in 2019. The AQI of April-May 2020 did not experience any "hazardous" event. In short, the AQI of April-May 2020 experienced the increasing of "good" and "moderate" level of AQI and decreasing of "unhealthy for sensitive groups," "unhealthy," and "very unhealthy" level that suggests the overall improvement of the air quality of Dhaka during the lockdown period, comparing to previous years. Overall, the AQI has been reduced by about $35 \%$ on average during April-May 2020 than the same period of the previous year. Figure 4 also shows a linear increment in the "unhealthy" and "very unhealthy" levels of AQI over the years from 2016 to 2019. Whereas the other three levels of AQI, such as "good," "moderate," and "unhealthy for sensitive groups" level followed a zigzag path instead of a linear path throughout their changes from 2016 to 2019 .

\section{Discussion}

In recent years, Dhaka's air pollution is a major public concern as the AQI of the city has been reported among the world's worst cities several times. The main source of air pollution in Dhaka includes emission from motor vehicles and industries, construction works, improper transportation of soil and sand through the city, emission from brick kilns around the city, dusty road with dirt, household combustion of fossil fuel, burning of solid waste in the open area nearer the city, and some transboundary pollution (DOE, 2014, 2019; Rahman et al., 2020). Table 2 shows that the concentration of $\mathrm{PM}_{2.5}$ has increased significantly after 2016 in the city. One of the causes might be the construction of multiple megaprojects of the city has begun after 2016, which boost the generation of air pollutants in several ways. For instance, the construction works narrowed down the road that kept vehicles longer time on the road burning more fossil fuel. Moreover, many public vehicles operating inside the city have no fitness, and they release finer particles due to the poor combustion of diesel and petrol (DOE, 2019). Therefore, the combination of unfit vehicle engines and exhaust filters (which exposes the poor enforcement of rules and laws), industrial emissions, and large-scale construction works contributed to the city being on the top of the world's polluted cities.

In these circumstances, the COVID-19 pandemic brought a halt in most of the anthropogenic sources of 
Fig. 3 Atmospheric concentration of $\mathrm{NO}_{2}, \mathrm{SO}_{2}$, and $\mathrm{CO}$ over Dhaka in April 2019 and 2020
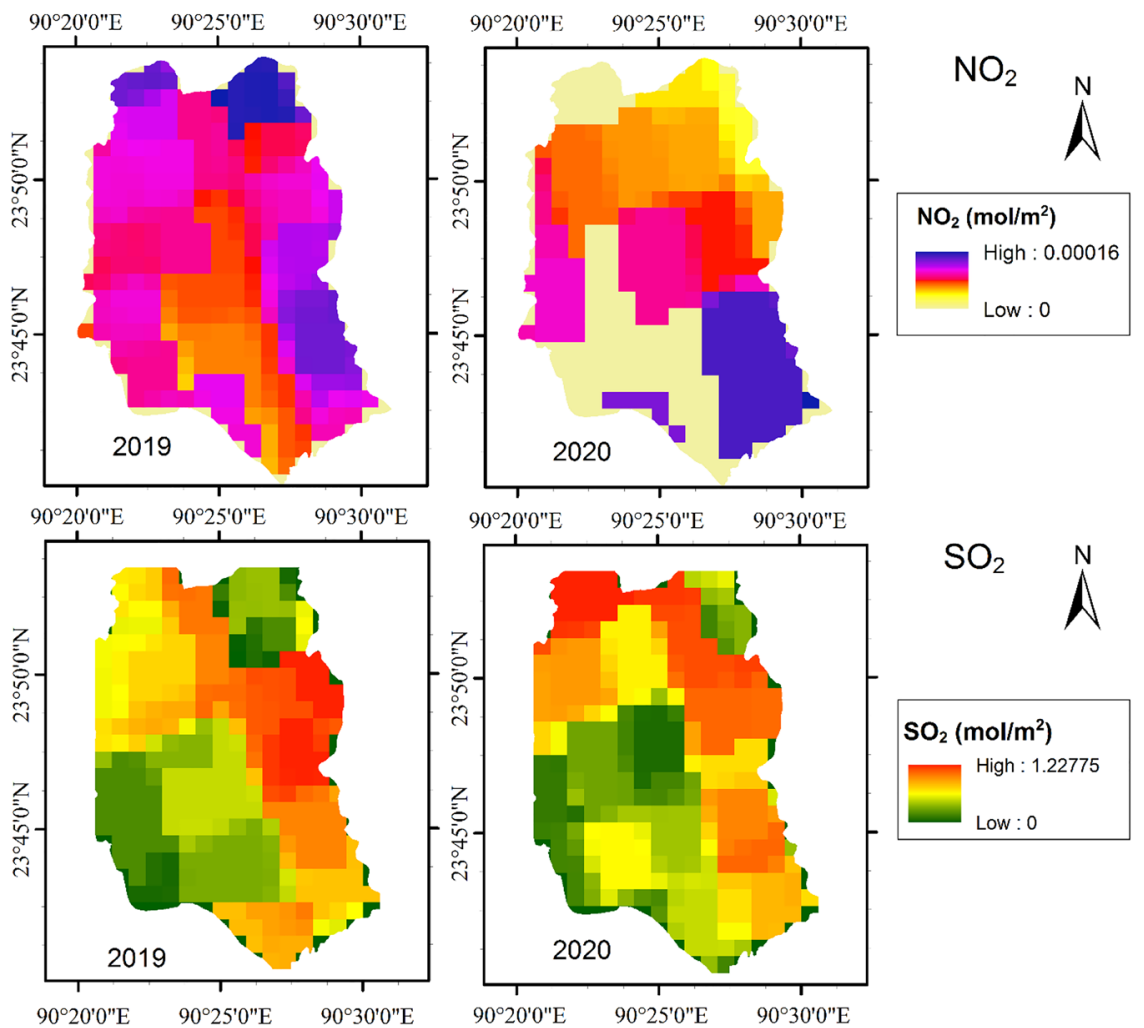

$90^{\circ} 20^{\prime} 0^{\prime \prime} \mathrm{E} \quad 90^{\circ} 25^{\prime} 0^{\prime \prime} \mathrm{E} \quad 90^{\circ} 30^{\prime} 0^{\prime \prime} \mathrm{E}$
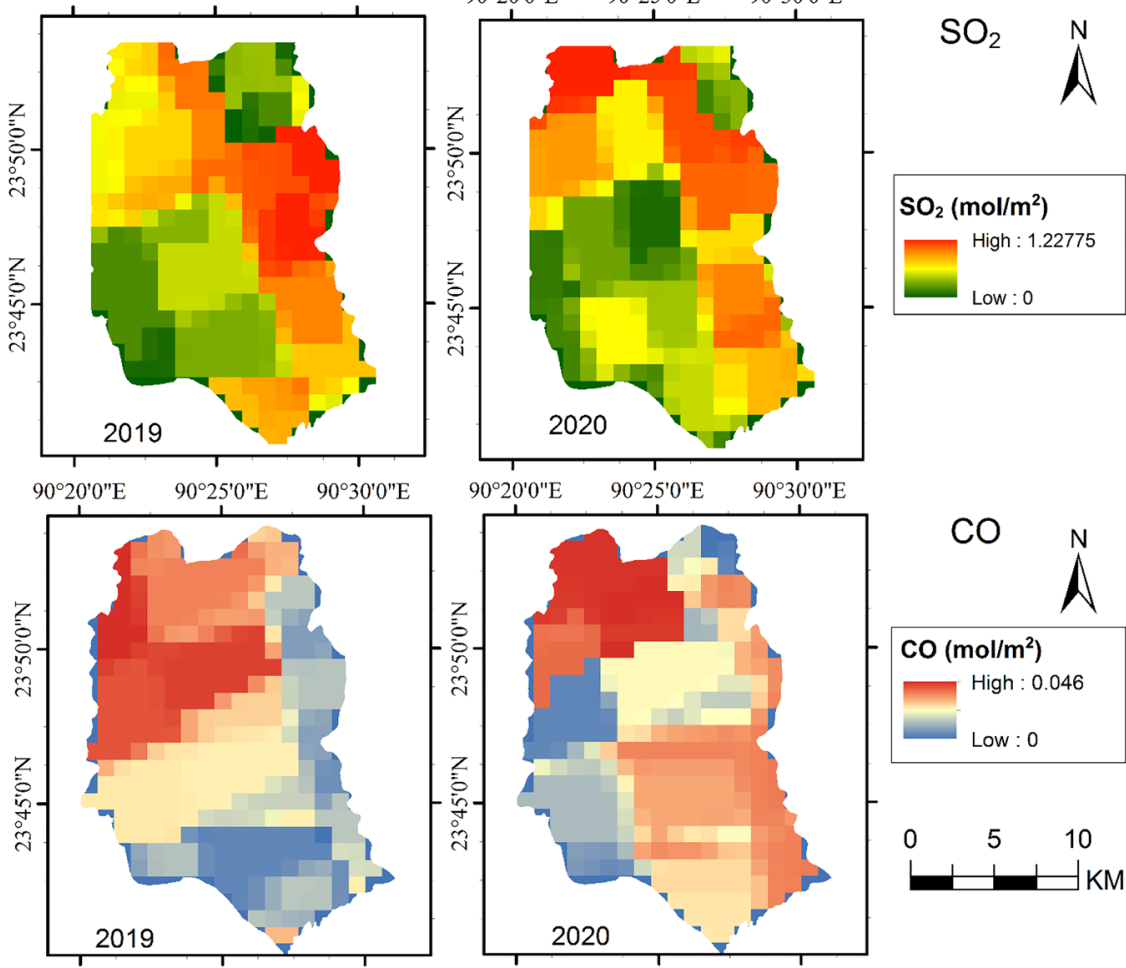

air pollution for a period of 2 months from April to May 2020. This lockdown resulted in a reduction of pollution; however, the magnitude of this reduction is not as much as anticipated before analyzing the data. Nevertheless, it has been found in other studies that not only Dhaka but other cities in the world also experienced pollution reduction in this lockdown period due to COVID-19. Table 4 shows the summary findings of different studies regarding air pollution reduction during the lockdown in several cities and countries of the world. For instance, an estimation found that the concentration of $\mathrm{PM}_{2.5}, \mathrm{NO}_{2}$, and $\mathrm{CO}$ have been reduced by 43,18 , and
$10 \%$, respectively, in Delhi during the lockdown (Sharma et al., 2020). Another assessment by Mahato et al. (2020) found that the concentration of $\mathrm{PM}_{2.5}, \mathrm{NO}_{2}$, and $\mathrm{CO}$ has been reduced by almost 50,53 , and $30 \%$, respectively, in Delhi. Both Sharma et al. (2020) and Mahato et al. (2020) also reported a reduction of AQI by 30 and $43 \%$ on average, respectively. Similar results have been found in other continents also. For example, the concentration of $\mathrm{NO}, \mathrm{NO}_{2}$, and $\mathrm{CO}$ has been reduced by up to 77,54 , and 65\%, respectively, in Sao Paulo, Brazil (Nakada \& Urban, 2020). Furthermore, Muhammad et al. (2020) found that the concentration of $\mathrm{NO}_{2}$ has decreased by 
60

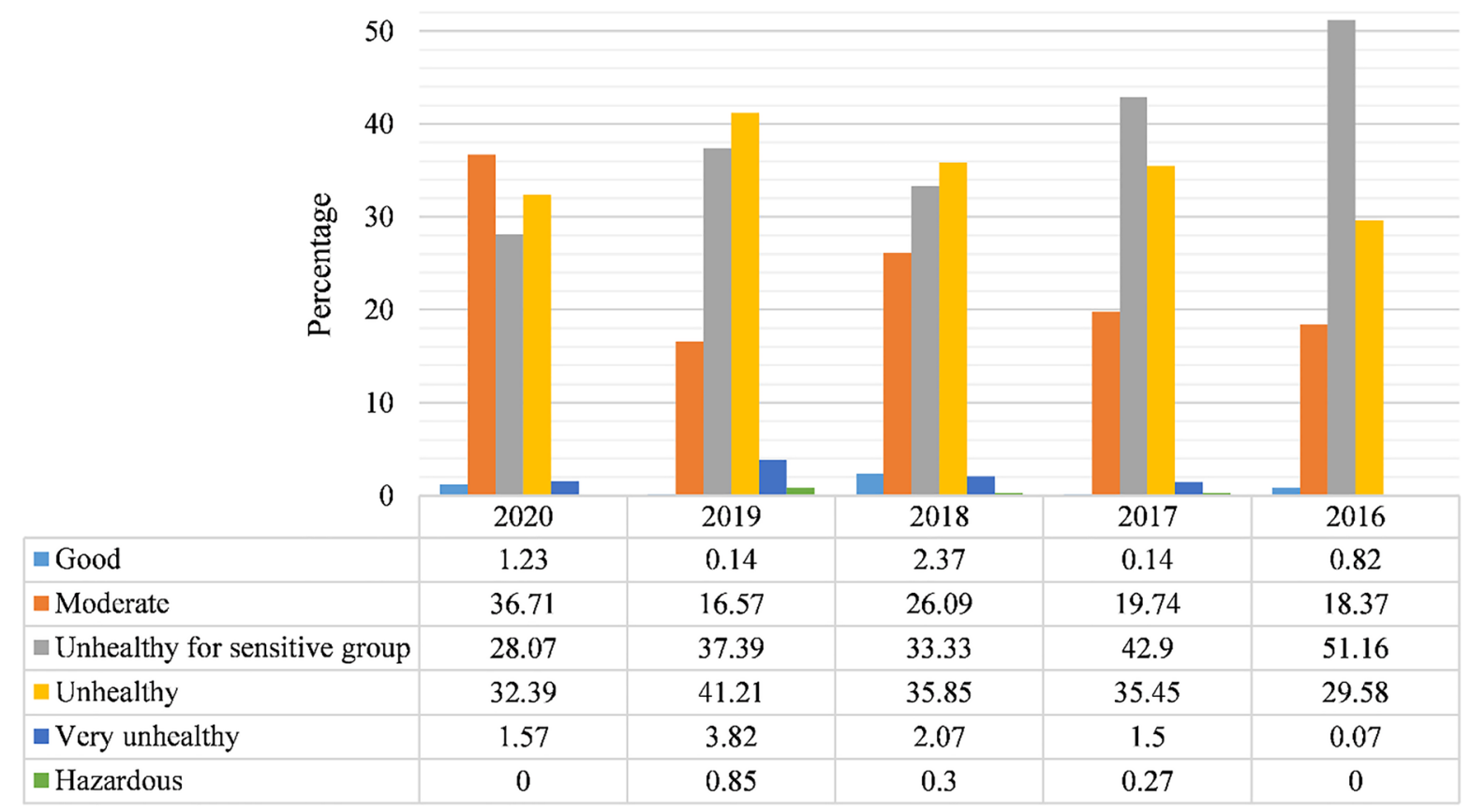

Fig. 4 The percentage of AQI classes during lockdown period and the same times of previous years

up to $20-30 \%$ in China, Spain, France, Italy, and the USA, which are the major epicenters of COVID-19. In comparison to Delhi and Sao Paulo, Dhaka has also experienced the reduction of $\mathrm{PM}_{2.5}, \mathrm{NO}_{2}$, $\mathrm{CO}$, and $\mathrm{AQI}$, but the extent or magnitude of the reduction is less than these two cities (23\% for $\mathrm{PM}_{2.5}, 30 \%$ for $\mathrm{NO}_{2}, 07 \%$ for $\mathrm{CO}$, and about $35 \%$ for AQI on average). Another significant observation is reported by Sharma et al. (2020) that the change in the concentration of $\mathrm{SO}_{2}$ is negligible in Delhi. In contrast, Dhaka shows a reduction in the mean concentration of $\mathrm{SO}_{2}$ by about $07 \%$ during the lockdown period compared to 2019.

Table 4 also shows that the air pollutants have significantly decreased in other parts of the world like Saudi Arabia, Seoul, Singapore, New York, Turkey, Baghdad, Iran, Malaysia, Auckland, Morocco, Kazakhstan, etc. The magnitude of the reduction of air pollutants varies with places and parameters. Besides, variation of results has also been found in the same city or country in different studies due to, most probably, the range of data and comparison method. Overall, two types of comparisons are found among the studies of Table 4. They are (i) a comparison of the concentration of air pollutants between "during lockdown period" and "same period" of previous years, and (ii) a comparison between pre-lockdown and during lockdown period. Furthermore, the numbers and types of parameters are not the same in all studies. However, despite the lack of homogeneity in the number of monitoring stations and parameters, all studies found that the concentration of air pollutants has been reduced during the lockdown period, except one study in Tehran (Faridi et al., 2020) which found an increase of $\mathrm{PM}_{2.5}$ and $\mathrm{PM}_{10}$ during the lockdown. The study reported that the main reasons for this finding are the lack of proper implementation of the lockdown and increase of private vehicle operation in the absence of public transport. Another homogeneity in the results is that the concentration of $\mathrm{NO}_{2}$ has been reduced to the maximum extent in most places compared to other pollutants (Table 4). A similar result has also been found in this study as the magnitude of $\mathrm{NO}_{2}$ reduction $(30 \%)$ has outnumbered other pollutants. Like the present study, the reduction of AQI has also been observed in Haryana, Uttar Pradesh, Baghdad, and Wuhan. In short, the results of similar studies in different parts of the world support the findings of the present study, although the magnitude of the findings varies. 
Table 4 Impact of COVID-19 lockdown on air pollutions in different cities/countries

\begin{tabular}{|c|c|c|c|c|c|c|c|c|}
\hline \multirow[t]{2}{*}{ No } & \multirow[t]{2}{*}{ City/province/country } & \multicolumn{6}{|c|}{ Changes of air pollution (\%) } & \multirow[t]{2}{*}{ Source } \\
\hline & & $\mathrm{PM}_{2.5}$ & $\mathrm{PM}_{10}$ & $\mathrm{NO}_{2}$ & $\mathrm{SO}_{2}$ & $\mathrm{CO}$ & AQI & \\
\hline 1 & Eastern Province, KSA $(\mathrm{M})^{*}$ & - & $21-70$ & $12-86$ & $9-30$ & $6-55$ & - & Anil and Alagha (2020) \\
\hline 2 & Seoul, South Korea** & 26.01 & - & - & - & - & - & Han and Hong (2020) \\
\hline 3 & Kannur, Kerala, India* & 53 & 61 & 71 & 62 & 67 & - & Resmi et al. (2020) \\
\hline 4 & Delhi, India** & 58 & 71 & 79 & 53 & 30 & - & Navinya et al. (2020) \\
\hline 5 & Kolkata, India** & 24 & 24 & 56 & 46 & 15 & - & Navinya et al. (2020) \\
\hline 6 & Bangalore, India** & 45 & 49 & 87 & 81 & 24 & - & Navinya et al. (2020) \\
\hline 7 & Singapore** & 29 & 23 & 54 & 52 & 6 & - & Li and Tartarini (2020) \\
\hline 8 & Delhi, UP, Haryana, India*** & - & - & - & - & - & $30-47$ & Gautam et al. (2020) \\
\hline 9 & New York, USA* & 36 & - & 51 & - & - & - & Zangari et al. (2020) \\
\hline 10 & Barcelona, Spain* & - & - & 50 & - & - & - & Baldasano (2020) \\
\hline 11 & Madrid, Spain* & - & - & 62 & - & - & - & Baldasano (2020) \\
\hline 12 & Istanbul, Turkey (M)** & $19-47$ & $32-43$ & $29-44$ & $34-69$ & $40-58$ & - & Sahin (2020) \\
\hline 13 & California, USA & 19 & - & 16 & - & 25 & - & Liu et al. (2021) \\
\hline 14 & California, USA* & 31 & - & 38 & - & 49 & - & Liu et al. (2021) \\
\hline 15 & Guanzhong, China* & 30 & 37 & 52 & 29 & 33 & - & Zhang et al. (2020) \\
\hline 16 & Baghdad, Iraq* & 15 & - & 35 & - & - & 13 & Hashim et al. (2021) \\
\hline 17 & Korea** & 45 & 36 & 20 & - & 17 & - & Ju et al. (2021) \\
\hline 18 & $\operatorname{Iran}(\mathrm{M})^{* *}$ & - & $2-30$ & $1-33$ & $5-28$ & $5-41$ & - & Broomandi et al. (2020) \\
\hline 19 & East China* & - & - & 30 & - & 20 & - & Filonchyk et al. (2020) \\
\hline 20 & Tehran, Iran** & +20.5 & +15.7 & - & - & - & - & Faridi et al. (2020) \\
\hline 21 & Wuhan, China** & 37 & - & 53 & - & - & 48 & Lian et al. (2020) \\
\hline 22 & Wuhan, China** & 37 & - & - & - & - & - & Zheng et al. (2020) \\
\hline 23 & Malaysia (M)** & $23-32$ & $26-31$ & $63-64$ & $9-20$ & $25-31$ & - & Kanniah et al. (2020) \\
\hline 24 & South America* & 40 & 44 & 60 & - & - & - & Mendez-Espinosa et al. (2020) \\
\hline 25 & Auckland, New Zealand (M)** & $8-17$ & $7-20$ & $34-57$ & - & - & - & Patel et al. (2020) \\
\hline 26 & Sao Paulo, Brazil** & - & - & 54.3 & - & 64.8 & - & Nakada and Urban (2020) \\
\hline 27 & Delhi, India* & 39 & 60 & 53 & & 30 & $31-54$ & Mahato et al. (2020) \\
\hline 28 & Sale, Morocco* & - & 75 & 96 & 49 & - & - & Otmani et al. (2020) \\
\hline 29 & West Bengal, India** & 59 & 58 & 55 & - & - & - & Sarkar et al. (2020) \\
\hline 30 & Almaty, Kazakhstan** & 21 & - & 35 & - & 49 & - & Kerimray et al. (2020) \\
\hline 31 & Wuhan, Italy, Spain, USA* & - & - & 30 & - & - & - & Muhammad et al. (2020) \\
\hline 32 & Delhi, India** & 43 & - & 18 & - & 10 & - & Sharma et al. (2020) \\
\hline
\end{tabular}

The values indicate the percentage of reduction, except the values with the ' + ' sign that means increase

$M$ Indicates multiple ground-based monitoring stations

“_ " Sign indicates that the research didn't study the respective parameter

*Indicates the comparison between pre-lockdown and during lockdown period

**Indicates the comparison between the lockdown period and the same period of previous years

It is now evident that the COVID-19-induced lockdown has reduced air pollution around the world, although the extent and magnitude of this phenomenon are not uniform in all cities or countries. It is also evident that the magnitude of pollution reduction in Dhaka is lower than in many other cities of different countries (Table 4). Some meteorological factors act as the driving force of the accumulation of pollutants. One of them is wind movement that carries the air pollutants (Dickson, 1961; Kim, 2011). Rahman et al., (2020) 
found that around $40 \%$ of $\mathrm{PM}_{2.5}$ in Dhaka City during the monsoon season are carried in by wind movement from neighboring regions. Besides, there are some demographic factors like total population and population density that have close links to air pollution (Cole $\&$ Neumayer, 2004). Since Dhaka is the world's most densely populated city (Demographia, 2020), the city dwellers combust a significant amount of fossil fuel (natural gas; charcoal, especially in slum areas) that might be a potential source of air pollution. Moreover, even though the public transport system was closed during the lockdown, private vehicles were allowed to drive in the city. Also, the implementation of lockdown became weak as the government declared to open the market and shopping mall in the second fortnight of May 2020. Furthermore, another reason could be transboundary pollution, especially particulate matter carried from northern and northeastern India (Begum et al., 2013). It is also found in a previous study that biomass burning aerosol from Pakistan, northern India, and Nepal affects the air quality of Dhaka (Ommi et al., 2017). India is mostly dependent on coal-burning for power generation and the coals they use produce a substantial amount of particulate matter and ash content (Begum and Hopke, 2018; Chandra \& Chandra, 2004). The Indian city of Kolkata, which is nearer to Dhaka among other Indian cities, has also experienced less pollution reduction $\left(24 \% \mathrm{PM}_{2.5}\right)$ during the lockdown period (Navinya et al., 2020). Therefore, there might be a contribution of coal and biomass-based emissions from neighboring regions to the less pollution reduction in Dhaka, which requires further investigation. In brief, the wind movement, population density (household combustion of fossil fuel), weak implementation of lockdown, regional pollution, etc., might be responsible for less reduction of air pollution in Dhaka.

The government of Bangladesh has undertaken several measures to mitigate ambient air pollution in Bangladesh so far, mostly related to industrial and vehicular emissions, including both command-andcontrol $(\mathrm{CAC})^{1}$ and market-based instruments $(\mathrm{MBI})^{2}$ strategies. Table 5 provides a summary of main air pollution abatement measures undertaken in the country with their commencing year and major outcomes. A significant step was taken in 1997 by enacting the Environment Conservation Rules (ECR), which set the national standard for the different air pollutants. The air pollutants that originated in Dhaka and other parts of the country are mostly from industrial and vehicular emissions. Therefore, several air pollution abatement measures like lead phase out from petrol, brick kiln stack height, ban on older vehicle import, ban on driving older vehicles, ban on two strokes three-wheelers, promotion of CNG vehicles, ban on the use of wood in brick kilns, and the ban on imports of high sulfur coal have been undertaken in last three decades. Among them, some measures have brought success in different degrees, while others were failing ventures (Table 5). The average concentration of lead in the ambient air of Dhaka decreased from $0.36 \mu \mathrm{g} /$ $\mathrm{m}^{3}$ in 1998 to $0.10 \mu \mathrm{g} / \mathrm{m}^{3}$ in 2005 (DOE, 2012). Another measure includes the ban of two strokes three-wheeler, introducing $\mathrm{CNG}$ three-wheeler and CNG conversion of other vehicles that caused an immediate reduction of particulate matter in the air of Dhaka (DOE, 2012). However, this measure could not alleviate the problem entirely due to other prevailing sources of pollution that remained uncontrolled. In a study, Wadud and Khan (2011) found that CNG cars run, on average, $30 \%$ more than petrol cars and the number of CNG cars has also been increased due to cheap fuel cost and affordability that probably cumulatively affected ambient air quality by releasing particulate matter. Out of two measures to control older vehicles with high emissions, the restriction on the import of older vehicles appeared as a moderately successful approach, but the eradication of them from the road did not see success due to poor enforcement.

There is two visible success in controlling brick kilns' emissions, such as a significant reduction in the use of fuelwood (approx. 90\%) and the conversion of Bulls Trench Kilns (BTK) to Fixed Chimney Kiln (FCK) with approved height (about 92\%) (Gomes \& Hossain, 2003; IIDFCL, 2009; WB, 2011). In contrast, the conversion of Fixed Chimney Kilns (FCK) into Zigzag Kilns/Hybrid Hoffman Kilns/Vertical Shaft Brick Kilns, according to 2010 Amendment of Brick Burning Law 1989, did not see widespread success due to lack of enforcement and proper implementation plan

\footnotetext{
1 The command-and-control strategy (CAC) is a strategy in which political authorities impose a behavior on citizens by enacting legislation and then using compliance mechanisms to ensure that people follow the law.

${ }^{2}$ Market-based instruments (MBI) are policy instruments used in environmental law and policy that use prices, interest, and other economic factors to provide polluters with incentives to reduce or remove negative environmental externalities.
} 
Table 5 Summary of air pollution abatement measures undertaken in Bangladesh

\begin{tabular}{|c|c|c|c|}
\hline Measures & Year & Result & Major outcomes \\
\hline Ban on use of wood in brick kilns & 1989 & Success-qualified & $\begin{array}{l}\text { Most of the brickfields are not using fuel- } \\
\text { wood. Coal became popular due to its low } \\
\text { price, which added a new dimension in } \\
\text { emissions }\end{array}$ \\
\hline Vehicle emissions standard & 1997, updated 2005 & Failure & $\begin{array}{l}\text { Set major legislation for emission control. The } \\
\text { standards are weaker compared to WHO } \\
\text { standards. Need to update }\end{array}$ \\
\hline Lead phase out from Petrol & 1999 & Success & $\begin{array}{l}\mathrm{Pb} \text { content in petrol lowered from } 0.8 \text { to } \\
0.4 \mathrm{~g} / \mathrm{l} \text {. Regular petrol was Pb free by } 1998 \text {, } \\
\text { while the premium petrol (locally known as } \\
\text { Octane) was made } \mathrm{Pb} \text { free in July } 1999\end{array}$ \\
\hline Ban on import of high Sulfur coal & 2001 & Failure & $\begin{array}{l}\text { The entrepreneurs were not convinced to } \\
\text { accommodate the policy due to the higher } \\
\text { price of low sulfur coal }\end{array}$ \\
\hline Brick kiln stack height & 2002 & Success & $\begin{array}{l}\text { Most of the brick kilns have been converted } \\
\text { from Bulls Trench Kilns to Fixed Chimney } \\
\text { Kilns }\end{array}$ \\
\hline Ban on driving older vehicles in Dhaka & 2002 & Repeated failure & $\begin{array}{l}\text { Did not work as per the plan as many pol- } \\
\text { luters will be financially affected. Need } \\
\text { comprehensive plan, including subsidy and } \\
\text { rehabilitation for affected parties }\end{array}$ \\
\hline Ban two strokes three-wheeler & 2002 & Success & $\begin{array}{l}\text { Immediate reduction in fine particulate matter } \\
\text { and multiple additional economic benefits. } \\
\text { However, couldn't able to suppress pollution } \\
\text { significantly due to other sources }\end{array}$ \\
\hline Promotion of CNG vehicles & 2002 & Success & $\begin{array}{l}\text { Reduced PM emission. However, the number } \\
\text { of vehicles and traffic congestion increased } \\
\text { significantly over the decades that sup- } \\
\text { pressed the positive impacts }\end{array}$ \\
\hline Lane based traffic & 2010 & Failure & $\begin{array}{l}\text { The policy failed due to a lack of education, } \\
\text { awareness, enforcement, effective transport } \\
\text { system, and appropriate plan }\end{array}$ \\
\hline Carpooling & 2010 & Failure & Did not work due to lack of feasibility \\
\hline $\begin{array}{l}\text { Introducing Zigzag Kilns, Hybrid Hoff- } \\
\text { man Kilns, Vertical Shaft Brick Kilns }\end{array}$ & 2010 & In process & $\begin{array}{l}\text { The suggested technologies are expensive. } \\
\text { Need comprehensive investment plan for } \\
\text { both big and small entrepreneurs as well as } \\
\text { strict enforcement }\end{array}$ \\
\hline Ban on older vehicle import & & Moderate success & $\begin{array}{l}\text { The buyers want to purchase reconditioned } \\
\text { cars due to less price. Will not succeed if the } \\
\text { overall economy is not developed }\end{array}$ \\
\hline Differentiated vehicle import tariff & & Success & $\begin{array}{l}\text { Although not a perfect MBI, strong public } \\
\text { support, smaller points of regulation mean } \\
\text { easier implementation }\end{array}$ \\
\hline Compulsory use of catalytic converter & Not enacted & - & - \\
\hline Colored kerosene & & Unclear & $\begin{array}{l}\text { The colored kerosene is now widely available. } \\
\text { The use of kerosene mixing with other fuel } \\
\text { is now under control }\end{array}$ \\
\hline Improved Cooking Stoves (ICS) Programs & & Success_qualified & $\begin{array}{l}\text { Significantly reduced indoor air pollution } \\
\text { and health risk for women who adopted the } \\
\text { measure }\end{array}$ \\
\hline
\end{tabular}

Compiled by authors from Begum et al. (2006); DOE (2012); Kirby (2015); Begum and Hopke (2018) 
(Kirby, 2015). As of 2017, the proportion of FCK, Zigzag Kiln, and Hybrid Hoffman Kiln was about 35, 63 , and $01 \%$, respectively (DOE, 2017). Similarly, the ban on importing high sulfur coal could not be implemented properly due to the price hike of bricks if manufactured using low sulfur coal. In addition to the abatement measures for ambient air pollution, one mitigation measure (Improved Cooking Stoves) seems to have the potential to alleviate indoor air pollution and it has already been successfully implemented in different parts of the country (WB, 2010; DOE, 2012). To conclude, Begum and Hopke (2018) reported that, although the ambient air pollution of Dhaka did not decrease significantly, but remained somewhat stable (as per long-term data from 1996 to 2015) despite the increase of emission sources, mostly due to the implementation of these measures, whichever brought positive consequences.

Overall, the air pollution abatement measures implemented in Bangladesh have certainly some outcomes in a positive way, but could not able to reduce the pollution level significantly due to lack of planning and enforcement; poor resource management; lack of awareness, knowledge, and skill; lack of financial affordability; and increase of population, vehicles, and industries. Therefore, the accumulated pollution level was so high that the COVID-19-induced lockdown did not decrease the ambient air pollution level in Dhaka City that much compared to other cities and countries of the world.

\section{Conclusion}

The main objective of the study was to investigate the reduction in the concentration of various air pollutants during COVID-19-induced lockdown in Dhaka City. To serve this purpose, the time-series data of $\mathrm{PM}_{2.5}$ were collected from the Air Quality Monitoring Station in US Embassy Dhaka from April-May 2016 to 2020, and the time-series data of $\mathrm{NO}_{2}, \mathrm{SO}_{2}, \mathrm{CO}$ were collected from Sentinel-5P for the period of April-May 2019 to 2020. Then, AQI was calculated based on $\mathrm{PM}_{2.5}$ from 2016 to 2018. On the other hand, AQI from 2019 to 2020 was calculated separately based on $\mathrm{PM}_{2.5}, \mathrm{NO}_{2}, \mathrm{SO}_{2}$, and $\mathrm{CO}$, and the highest value is considered for analysis. The study found that the concentrations of all pollutants, including $\mathrm{PM}_{2.5}$, $\mathrm{NO}_{2}, \mathrm{SO}_{2}$, and $\mathrm{CO}$, have been decreased during the lockdown period, compared to their concentration in the same period of the previous year. The highest degree of concentration reduction occurred in the case of $\mathrm{NO}_{2}$, followed by $\mathrm{PM}_{2.5}, \mathrm{SO}_{2}$, and $\mathrm{CO}$. The AQI also decreased by more than one-third on average compared to its extent in the previous year. The extent of pollution reduction in Dhaka is relatively lower compared to the capital city of the neighboring country, Delhi. It is also lower than some other cities and countries like Sao Paulo, Wuhan, Spain, Italy, the USA, etc. The overall findings suggest that the extent of air pollution has moderately decreased during the lockdown period because of the poor implementation of lockdown in Dhaka as well as other remaining pollution sources like household combustion, operation of private vehicles, solid waste burning, transboundary pollution, etc. The findings of the study will provide some food for thought to the policymakers that strict measures to control the pollution sources might be useful to improve the city air.

\section{Appendix}

Table 6 Breakpoints and their corresponding AQI values of different pollutants

1-h $\mathrm{SO}_{2}$ values do not define higher AQI values $(\geq 200)$. AQI values of 200 or higher are calculated with 24-h SO concentrations

US EPA (2018)

\begin{tabular}{|c|c|c|c|c|c|}
\hline \multicolumn{4}{|l|}{ Breakpoints } & \multirow[t]{2}{*}{ AQI value } & \multirow[t]{2}{*}{ AQI category } \\
\hline $\mathrm{PM}\left(\mu \mathrm{g} / \mathrm{m}^{3}\right) 24 \mathrm{~h}$ & $\mathrm{CO}(\mathrm{ppm}) 8 \mathrm{~h}$ & $\mathrm{SO}_{2}(\mathrm{ppb}) 1 \mathrm{~h}$ & $\mathrm{NO}_{2}(\mathrm{ppb}) 1 \mathrm{~h}$ & & \\
\hline $0.0-12.0$ & $0.0-4.4$ & $0-35$ & $0-53$ & $0-50$ & Good \\
\hline $12.1-35.4$ & $4.5-9.5$ & $36-75$ & $54-100$ & $51-100$ & Moderate \\
\hline $35.5-55.4$ & $9.5-12.4$ & $76-185$ & $101-360$ & $101-150$ & $\begin{array}{l}\text { Unhealthy for } \\
\text { sensitive } \\
\text { group }\end{array}$ \\
\hline $55.5-150.4$ & $12.5-15.4$ & $(186-304)^{1}$ & $361-649$ & $151-200$ & Unhealthy \\
\hline $150.5-250.4$ & $15.5-30.4$ & $(305-604)^{1}$ & $650-1249$ & $201-300$ & Very unhealthy \\
\hline $250.5-350.4$ & $30.5-40.4$ & $(605-804)^{1}$ & $1250-1649$ & $301-400$ & Hazardous \\
\hline $350.5-500.4$ & $40.5-50.4$ & $(805-1004)^{1}$ & $1650-2049$ & $401-500$ & Hazardous \\
\hline
\end{tabular}


Acknowledgements The authors are thankful to K. M. Shakik Ahmed Walid for his help during the revision period.

Data availability Data will be available on reasonable request.

\section{Declarations}

Conflict of interest The authors declare no competing interests.

\section{References}

Anil, I. and Alagha, O. (2020). The impact of COVID-19 lockdown on the air quality of Eastern Province, Saudi Arabia. Air Quality, Atmosphere \& Health. https://doi.org/10. 1007/s11869-020-00918-3

Baldasano, J. M. (2020). COVID-19 lockdown effects on air quality by $\mathrm{NO}_{2}$ in the cities of Barcelona and Madrid (Spain). Science of the Total Environment, 741, 140353.

Begum, B. A., \& Hopke, P. K. (2018). Ambient air quality in Dhaka Bangladesh over two decades: Impacts of policy on air quality. Aerosol and Air Quality Research, 18, 1910-1920.

Begum, B. A., Biswas, S. K., \& Hopke, P. K. (2006). Impact of banning of two-stroke engines on airborne particulate matter concentrations in Dhaka, Bangladesh. Journal of the Air \& Waste Management Association, 56, 85-89.

Begum, B. A., Hopke, P. K., \& Markwitz, A. (2013). Air pollution by fine particulate matter in Bangladesh. Atmospheric Pollution Research, 4(1), 75-86.

Brook, R. D., Franklin, B., Cascio, W., Hong, Y., Howard, G., Lipsett, M., Luepker, R., Mittleman, M., Samet, J., Smith, S. C., Jr., \& Tager, I. (2004). Expert panel on population and prevention science of the American Heart Association. Air pollution and cardiovascular disease: A statement for healthcare professionals from the Expert Panel on Population and Prevention Science of the American Heart Association. Circulation, 109(21), 2655-2671.

Broomandi, P., Karaca, F., Nikfal, A., Jahanbakhshi, A., Tamjidi, M., \& Kim, J. R. (2020). Impact of COVID-19 event on the air quality in Iran. Aerosol and Air Quality Research, 20, 1793-1804.

Chandra, A., \& Chandra, H. (2004). Impact of Indian and imported coal on Indian thermal power plants. Journal of Scientific \& Industrial Research, 63, 156-162.

Cole, M. A., \& Neumayer, E. (2004). Examining the impact of demographic factors on air pollution. Population and Environment, 26(1), 5-21.

Demographia (2020). World urban areas 16th annual edition: 2020.06. www.demographia.com/db-worldua.pdf Accessed 04 July 2020.

Department of Environment (DOE). (2012). Air pollution reduction strategy for Bangladesh. Department of Environment, Government of Bangladesh.

Department of Environment (DOE) (2014). Identification and apportionment of sources from air particulate matter at urban environments in Bangladesh. Department of
Environment, Ministry of Environment, Forest and Climate Change, Dhaka.

Department of Environment (DOE). (2017). National Strategy for Sustainable Brick Production in Bangladesh. Dhaka: MoEFCC, Government of the People's Republic of Bangladesh.

Department of Environment (DOE) (2019) Sources of air pollution in Bangladesh: Brick kiln and vehicle emission scenario. Clean Air and Sustainable Environment Project, Department of Environment, Ministry of Environment, Forest and Climate Change, Dhaka.

Dickson, R. R. (1961). Meteorological factors affecting particulate air pollution of a city. Bulletin American Meteorological Society, 42(8), 556-560.

Faridi, S., Yousefian, F., Niazi, S., Ghalhari, M. R., Hassanvand, M. S., \& Naddafi, K. (2020). Impact of SARS-CoV-2 on ambient air particulate matter in Tehran. Aerosol and Air Quality Research. https://doi.org/10.4209/aaqr.2020.05.0225

Filonchyk, M., Hurynovich, V., Yan, H., Gusev, A., \& Shpilevskaya, N. (2020). Impact assessment of COVID-19 on variations of $\mathrm{SO}_{2}, \mathrm{NO}_{2}, \mathrm{CO}$ and $\mathrm{AOD}$ over East China. Aerosol and Air Quality Research, 20, 1530-1540.

Gautam, A. S., Dilwaliya, N. K., Srivastava, A., Kumar, S., Bauddh, K., Siingh, D., Shah, M. A., Singh, K., \& Gautam, S. (2020). Temporary reduction in air pollution due to anthropogenic activity switch-off during COVID-19 lockdown in northern parts of India. Environment, Development and Sustainability. https://doi.org/10.1007/s10668-020-00994-6

Gomes, E., \& Hossain, I. (2003). Transition from traditional brick manufacturing to more sustainable practices. Energy for Sustainable Development, VII(2), 66-76.

Han, C., \& Hong, Y. (2020). Decrease in ambient fine particulate matter during COVID-19 crisis and corresponding health benefits in Seoul, Korea. International Journal of Environmental Research and Public Health, 17, 5279.

Hashim, B. M., Al-Naseri, S. K., Al-Maliki, A., \& Al-Ansari, N. (2021). Impact of COVID-19 lockdown on $\mathrm{NO}_{2}, \mathrm{O} 3$, $\mathrm{PM}_{2.5}$ and $\mathrm{PM}_{10}$ concentrations and assessing air quality changes in Baghdad. Iraq. Science of the Total Environment, $754,141978$.

IIDFCL. (2009). Improved kiln efficiency in the brick making industry in Bangladesh [Hybrid Hoffman Kiln project]. Environmental Management Framework.

IPCC. (2007). Changes in atmospheric constituents and in radiative forcing (fourth assessment report). Cambridge University Press.

IQAir (2018). World air quality report: Region and city $P M_{2.5}$. Goldach: IQAir. https://www.iqair.com/worldmost-polluted-cities/world-air-quality-report-2018-en. pdf, Accessed 18 April 2021.

IQAir (2019). World air quality report: Region and city $P M_{2.5}$. Goldach: IQAir. https://www.greenpeace.org/static/planet4thailand-stateless/2020/02/91ab34b8-2019-world-air-report. pdf, Accessed 18 April 2021.

IQAir (2020). World Air Quality Report: Region and City PM 2.5 . Goldach: IQAir. https://www.iqair.com/world-most-pollutedcities/world-air-quality-report-2020-en.pdf, Accessed 18 April 2021.

Ju, M. J., Oh, J., \& Choi, Y. (2021). Changes in air pollution levels after COVID-19 outbreak in Korea. Science of the Total Environment, 750, 141521. 
Kanniah, K. D., Zaman, N. A. F. K., Kaskaoutis, D. G., \& Latif, M. T. (2020). COVID-19's impact on the atmospheric environment in the Southeast Asia region. Science of the Total Environment, 736, 139658.

Kerimary, A., Baimatova, N., Ibragimova, O. P., et al. (2020). Assessing air quality changes in large cities during COVID-19 lockdowns: The impacts of traffic-free urban conditions in Almaty Kazakhstan. Science of the Total Environment, 730, 139179.

Kim, Y. (2011). Impact of traffic flows and wind directions on air pollution concentrations in Seoul, Korea. Atmospheric Environment, 45, 2803-2810.

Kirby, L. (2015). Brick kilns in Bangladesh. Leadership Academy for Development, https://cddrl.fsi.stanford.edu/publication/ brick-kilns-bangladesh. Retrieved March 30, 2021

Li, J., \& Tartarini, F. (2020). Changes in air quality during the COVID-19 lockdown in Singapore and associations with human mobility trends. Aerosol and Air Quality Research, 20, 1748-1758.

Lian, X., Huang, J., Huang, R., Liu, C., Wang, L., \& Zhang, T. (2020). Impact of city lockdown on the air quality of COVID-19-hit of Wuhan city. Science of the Total Environment, 742, 140556.

Lin, J., \& Lee, L. C. (2004). Characterization of the concentration and distribution of urban submicron (PM1) aerosol particles. Atmospheric Environment, 38, 469-475.

Liu, Q., Harris, J. T., Chiu, L. S., Sun, D., Houser, P. R., Yu, M., Duffy, D. Q., Little, M. M., \& Yang, C. (2021). Spatiotemporal impacts of COVID-19 on air pollution in California, USA. Science of the Total Environment, 750, 141592.

Mahato, S., Pal, S., \& Ghosh, K. G. (2020). Effect of lockdown amid COVID-19 pandemic on air quality of the megacity Delhi India. Science of the Total Environment, 730, 139086.

Mendez-Espinosa, J. F., Rojas, N. Y., Vargas, J., Pachon, J. E., Belalcazar, L. C., \& Ramirez, O. (2020). Air quality variations in Northern South America during the COVID-19 lockdown. Science of the Total Environment. https://doi. org/10.1016/j.scitotenv.2020.141621

Muhammad, S., Long, X., \& Salman, M. (2020). COVID-19 pandemic and environmental pollution: A blessing in disguise? Science of the Total Environment, 728, 138820.

Nakada, L.Y.K. and Urban, R.C. (2020). COVID-19 pandemic: Impacts on the air quality during the partial lockdown in São Paulo state, Brazil. Science of the Total Environment. https://doi.org/10.1016/j.scitotenv.2020. 139087

Namdeo, A., \& Bell, M. C. (2005). Characteristics and health implications of fine and coarse particulates at roadside, urban background and rural sites in UK. Environment International, 31, 565-573.

Navinya, C., Patidar, G., \& Phuleria, H. C. (2020). Examining effects of the COVID-19 national lockdown on ambient air quality across Urban India. Aerosol and Air Quality Research, 20, 1759-1771.

Ommi, A., Emami, F., Zikova, N., Hopke, P. K., \& Begum, B. A. (2017). Trajectory-based models and remote sensing for biomass burning assessment in Bangladesh. Aerosol Air Qual. Res., 17, 465-475.
Otmani, A., Benchrif, A., Tahri, M., et al. (2020). Impact of Covid-19 lockdown on PM10, $\mathrm{SO}_{2}$ and $\mathrm{NO}_{2}$ concentrations in Salé City (Morocco). Science of the Total Environment, $735,139541$.

Patel, H., Talbot, N., Salmond, J., Dirks, K., Xie, S., \& Davy, P. (2020). Implications for air quality management of changes in air quality during lockdown in Auckland (New Zealand) in response to the 2020 SARS-CoV-2 epidemic. Science of the Total Environment, 746, 141129.

Perez, P., \& Reyes, J. (2002). Prediction of maximum of 24-h average of PM10 concentrations $30 \mathrm{~h}$ in advance in Santiago, Chile. Atmospheric Environment, 36, 4555-4561.

Rahman, M.M., Begum, B.A., Hopke, P.K. and Nahar, K. (2020). Assessing the $\mathrm{PM}_{2.5}$ impact of biomass combustion in megacity Dhaka, Bangladesh. Environmental Pollution, 264, 114798. https://doi.org/10.1016/j.envpol.2020. 114798

Resmi, C. T., Nishanth, T., Kumar, M. K. S., Manoj, M. G., Balachandramohan, M., \& Valsaraj, K. T. (2020). Air quality improvement during triple-lockdown in the coastal city of Kannur, Kerala to combat Covid-19 transmission. PeerJ, 8, e9642.

Sahin, U. A. (2020). The effects of COVID-19 measures on air pollutant concentrations at urban and traffic sites in Istanbul. Aerosol and Air Quality Research, 20, 1874-1885.

Sarkar, M., Das, A. and Mukhopadhyay, S. (2020). Assessing the immediate impact of COVID-19 lockdown on the air quality of Kolkata and Howrah, West Bengal, India. https://doi.org/10.21203/rs.3.rs-38142/v1

Sharma, S., Zhang, M., GaoAnshika, J., Zhang, H., \& Kota, S. H. (2020). Effect of restricted emissions during COVID19 on air quality in India. Science of the Total Environment, $728,138878$.

Epa, U. S. (2018). Technical assistance document for the reporting of daily air quality - The Air Quality Index $(A Q I)$. Environmental Protection Agency.

Van Tienhoven, A.M., Scholes, M.C. (2003). Air pollution impacts on vegetation in South Africa. Air pollution impacts on crops and forests: a global assessment. Imperial College Press, London 237-262.

Wadud, Z., \& Waitz, I. (2011). Comparison of air qualityrelated mortality impacts of different transportation modes in the United States. Transportation Research Record, 2233, 99-109.

WHO. (2006). Air quality guidelines: Global update 2005: Particulate matter, ozone, nitrogen dioxide, and sulphur dioxide. World Health Organization.

World Bank (WB). (2010). Improved cookstoves and better health in Bangladesh: Lessons from household energy and sanitation programs. The World Bank.

World Bank (WB) (2011). Introducing energy-efficient clean technologies in the brick sector of Bangladesh. Report No. 60155-BD. Washington DC: The World Bank.

Zangari, S., Hill, D. T., Charette, A. T., \& Mirowsky, J. E. (2020). Air quality changes in New York City during the COVID-19 pandemic. Science of the Total Environment, 742, 140496.

Zhang, K., Leeuw, G. D., Yang, Z., Chen, X., \& Jiao, J. (2020). The impacts of the COVID-19 lockdown on air quality in the Guanzhong Basin China. Remote Sensing, 12, 3042. 
Zheng, H., Kong, S., Chen, N. et al. (2020) Significant changes in the chemical compositions and sources of $\mathrm{PM}_{2.5}$ in Wuhan since the city lockdown as COVID-19. Science of the Total Environment, 739, 140000.
Publisher's Note Springer Nature remains neutral with regard to jurisdictional claims in published maps and institutional affiliations. 